\title{
Rent-seeking and asset-price inflation: a total-returns profile of economic polarization in America*
}

\author{
Michael Hudson** \\ President, Institute for the Study of Long-Term Economic Trends (ISLET), Forest Hills, NY and Research \\ Fellow, Levy Economics Institute of Bard College, Annandale-on-Hudson, NY, USA
}

This paper reconstructs the National Income and Product Accounts to add asset-price ('capital') gains to national income to derive a measure of total returns. It also treats rent-extraction as a charge against national income and GDP, not as a contribution to national output. Segregating the Finance, Insurance, and Real Estate sector from the rest of the private sector shows that most growth in wealth and income derives from rentier activities - from the dynamic of finance capitalism more than that of industrial capitalism.

Keywords: FIRE sector, economic rent in the NIPA, financialization

JEL codes: $G 12, E 01, E 12, G 12, R 30$

\begin{abstract}
'More than half of all Americans feel pressure and strain, according to the April 2019 Global Emotions Report published by Gallup. Most (55\%) Americans recall feeling stressed much of the day in 2018. That's more than in all but three countries globally. Nearly half of Americans felt worried (45\%) and more than a fifth (22\%) felt angry. "Even as their economy roared, more Americans were stressed, angry and worried last year than they have been at many points during the last decade," Julie Ray, a Gallup editor, wrote in the summary report.'
\end{abstract}

USA Today (26 April 2019)

'For me the relevant issue isn't what I report on the bottom line, it's what I get to keep. ... I love depreciation.'

Donald Trump, Trump: The Art of the Deal (1987)

\section{INTRODUCTION AND OVERVIEW: A DEBT-STRAPPED ERA OF DOWNWARD MOBILITY}

The stock market has soared to all-time highs, and the unemployment rate has fallen to a decade-low. Yet the Federal Reserve's Report on the Economic Well-Being of U.S. Households in 2018 reports that 39 percent of Americans do not have $\$ 400$ cash available for a medical or other emergency, and that a quarter of adults skipped medical

* This article is based on work with Dirk Bezemer, with charts by Howard Reed, funded by Democracy Collaborative as part of its Next System project.

** Email: hudson.islet@gmail.com. 
care in 2018 because they could not afford it (Federal Reserve 2018, p. 22, fig. 11). The latest estimates by the US Government Accountability Office (GAO) report that nearly half (48 percent) of households headed by someone 55 and older lack any retirement savings or pension benefits. Even in what the press calls an economic boom, most Americans feel stressed and many are chronically angry and worried. According to a survey by the American Psychological Association (2015), financial worry is the 'number one cause of stress in America today.'

The Federal Reserve describes them as suffering from 'financial fragility.' What is fragile is their economic status and self-worth, teetering on the brink of downward mobility. Living in today's financialized economy creates stresses that seem more damaging emotionally than living in a poor country. America certainly is not a poor country, but its wealth and income growth are so highly concentrated that much of its population is emotionally worse off than that of almost any other country in the world.

The problem is not overall income or wealth, but the fact that the financial sector's soaring wealth and income takes the form of a steepening liability for that of the rest of the economy. The main culprit is debt, or more specifically, the burden of having to pay it back - with penalties, fees and lower credit ratings. The mainstream press depicts the rising market price of homes as a benefit to homeowners, a capital gain as if they almost were real-estate speculators or capitalists in miniature, not wage-earners running up debt. GDP statisticians include the rise in valuation of owner-occupied real estate and the rising rents it saves home-owners from having to pay as adding to GDP.

But this price rise comes at a cost, in the form of higher mortgage debt. New owners must pay more and more to their banks for the credit needed by homes rising in price. But they do not receive a corresponding income for living in their homes, even if rents rise in their neighborhood. As a result, debt-financed home-price inflation has become a major factor squeezing family budgets in today's world.

This debt should rightly be viewed as a subtrahend, as it appears on the liabilities side of the balance sheet. And when debtors fall behind, they have to pay penalty fees and higher interest rates. Yet these payments are added to today's GDP measure, even as they leave less family income available to be spend on products. As a result, the logical starting point to understanding the US economy should be to look at the magnitudes involved. The key is not so much GDP as capital (asset-price) gains and the offsetting debt burden financing these gains. This financialized overhead is not real growth. It does not make the economy richer. This paper explains why, and provides a sense to magnitude for rent extraction and capital gains relative to GDP.

\section{DEBT-FINANCED ASSET-PRICE INFLATION AS FINANCE CAPITALISM'S DEFINING DYNAMIC}

To explain the economy's polarization and the dangerous position in which it now stands, we show that the industrial production-and-consumption economy described in the National Income and Product Accounts (NIPA) takes a back seat to the balance-sheet economy of wealth, borrowing, and speculation. Figure 1 charts the annual change in land valuations (as reported by the Federal Reserve's Flow of Funds report), bond and stock-market gains or losses compared to annual changes in GDP. In almost every year, asset-price gains in the real-estate and capital markets far outpace the gains (or shrinkage) in reported GDP. And when land prices plunged in 2008 as a result of the banking system's bad loans, this caused a stock-market plunge and GDP decline. 


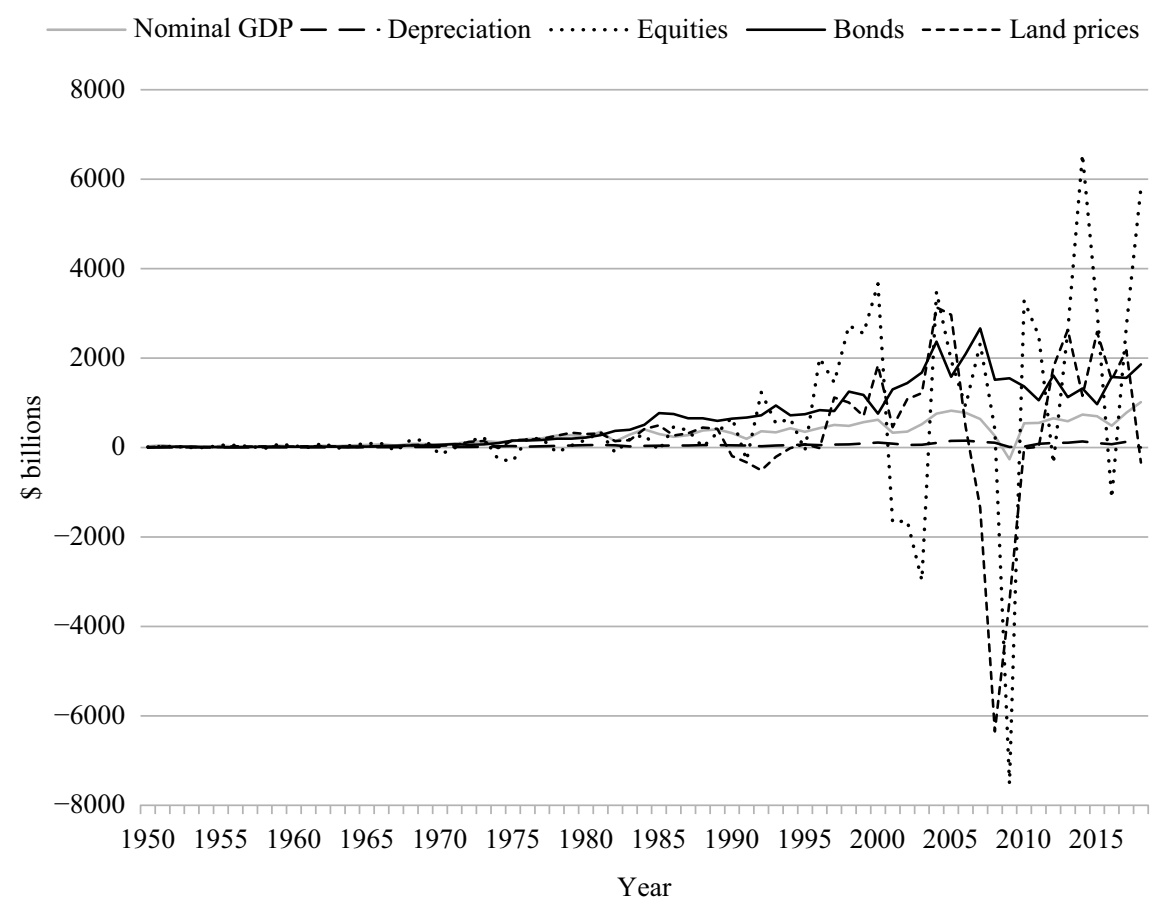

Figure 1 Year-on-year changes in GDP and the major components of asset-price gains (nominal, \$ billions)

But bond prices have soared since 1980. The bond market's gains have kept pace with US land-price gains, as Figure 2 shows. Financial-asset prices rise as inexorably as the land prices on which classical economists focused as the key to the nineteenth century's rentier economy. Figure 2 shows that the magnitudes of bond and land-price gains have doubled relative to GDP since the 1980s. Figure 3 shows the dollar figures: the asset price gains dwarf incomes in the real economy. This financial reality of how the US economy works is no longer captured in GDP statistics. That is why in this paper we will introduce a total returns measure: income plus capital gains. Studying the distribution of total returns tells us more about polarization in America than the official statistics. So the landlord class dominating wealth has now evolved into a financial class. Figures 2 and 3 show the extent to which finance capitalism has overtaken what were expected to be the trends of industrial capitalism.

The magnitude of 'total returns' as compared to GDP, and their concentration at the hands of the wealthiest 10 percent, has become the distinguishing feature of today's finance capitalism: rising asset valuations go hand-in-hand with the economy's increasing focus on extraction of economic rent (discussed below). This is the opposite of what classical free-market reformers hoped would be (and indeed, seemed to be) the political dynamic of industrial capitalism in the nineteenth century. We explain the rising role of rentier income by isolating this rent, above all in the Finance, Insurance, and Real Estate (FIRE) sector.

It's all about capital gains - and most such asset-price gains are fueled by bank credit, that is, by debt financing. The creation and trading of property and financial 
438 Review of Keynesian Economics, Vol. 9 No. 4

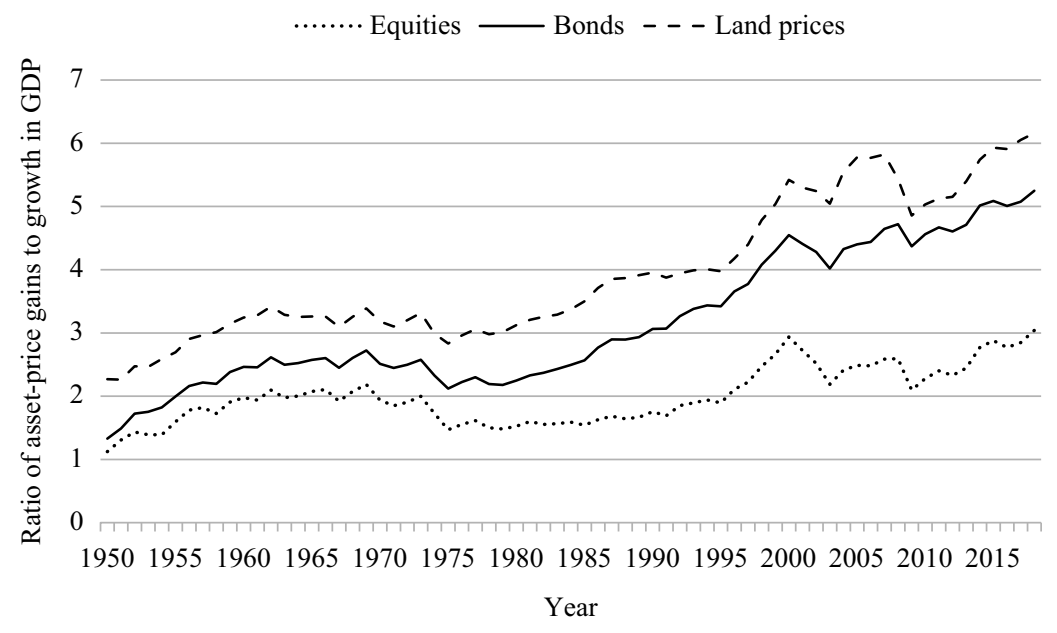

Figure 2 Asset-price gains as multiples of growth in GDP, 1950-2018

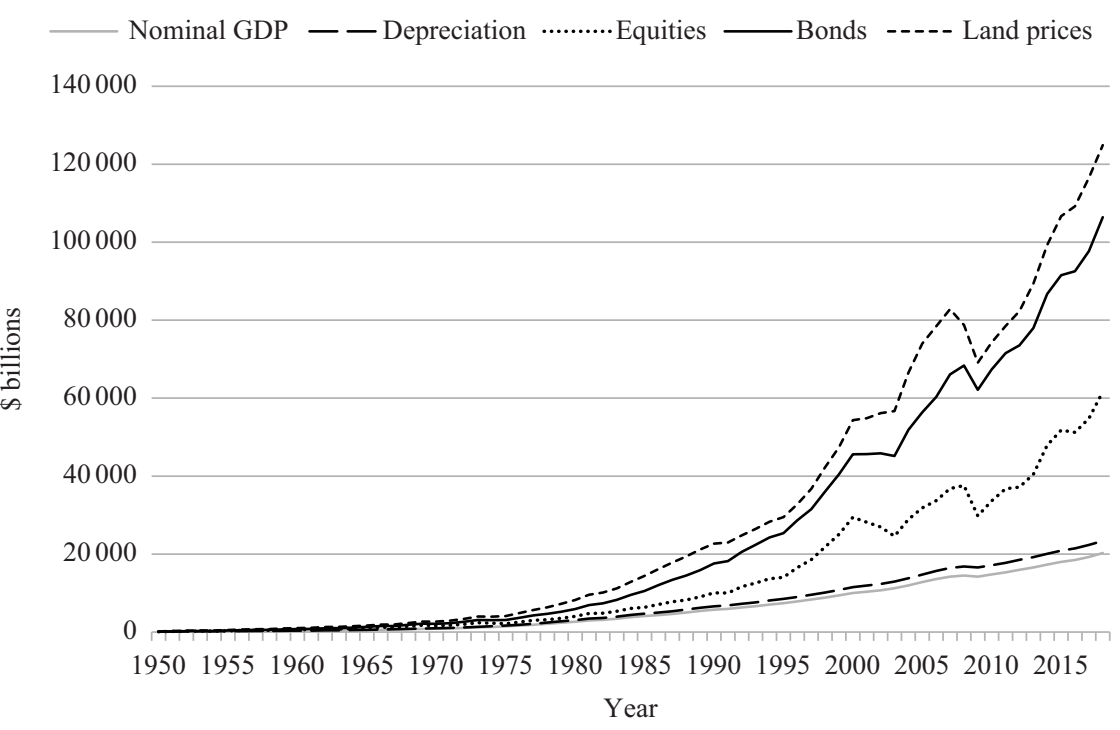

Figure 3 Cumulative total returns: the sum of GDP, equities, bonds, land values, and depreciation, 1950-2018 (nominal, \$ billions)

assets at rising prices has been fueled by rising debt levels owed to the financial sector. The primary aim of today's commercial and central banking, especially since 2008, has been to fuel capital gains by more credit/debt creation.

The financial sector's returns are best seen not as real wealth on the asset side of the balance sheet, but as overheads on the liabilities side. And the process is multi-layered: income accruing to the financial wealth owned by the top 10 percent is paid mainly by 
the bottom 90 percent in the form of rising debt service and other returns to financial and other property.

In the textbook models of industrial capitalism's mass production and consumption, an asset's price is determined by its cost of production. If the price rises above this level, competitors will offer it at cost, keeping prices in line with actual value, that is, the necessary cost of production. But in financialized economies an asset's price is determined by how much credit buyers can borrow to buy it. A home is worth as much as a bank will lend to a bidder, not limited by its cost of production. Furthermore, this bank mortgage lending and hence the price of housing has tended to run far ahead of actual rent levels.

The engine of industrial capitalism and its consumer society was a positive feedback loop in which widely shared income growth, expanding consumption, and markets generated yet more investment and growth. By contrast, the feedback loop of financial capitalism is an exponential growth of debt, driving up asset prices and hence requiring yet more borrowing to buy homes, retirement income, and other assets. This dynamic extracts more and more interest and amortization from the economy, shrinking markets for real output.

Corporate management and investment today is mainly about obtaining capital gains for real estate, stocks, and bonds than about earning income. We illustrate this by charting the flow of income and capital gains in the real-estate sector to show the dominance of asset-price gains over net rental income - and how rent is for paying interest in our financialized economy. Likewise, corporate income is spent (and new debt taken on) largely for stock buy-backs to raise share prices. The resulting dynamic is exponential and destabilizing.

Our conceptual framework to chart the course of today's financial capitalism shows that the magnitude of changes in asset values and debt levels far overshadows the NIPA framework that provided the statistics for industrial capitalism's production and real investment. The drive to make wealth purely by balance-sheet asset values and rent extraction eats into the circular flow of production and consumption. That has two consequences, indicated by the black panels in Figure 4.

The first dynamic at work is the tendency for the volume of debt to increase faster than income. This increases financial fragility as debt-income ratios rise in order to keep up with debt-inflated asset prices. At first, rising debt service is paid out of capital gains - for instance, by home-owners taking out home equity loans (second mortgages) to carry this bank debt. That is the Ponzi scheme character at work. That makes today's financialized growth model unsustainable, because in the end many debts cannot be paid. Trying to pay them leaves less and less disposable personal income available to spend on goods and services. The economy shrinks, people lose their jobs, and loan defaults rise.

We thus face a stark choice: either debt write-downs followed by renewed and more equitable income growth; or continuing wealth concentration, accelerating debt growth, widespread foreclosures and another crash. This choice can be postponed, but it cannot be avoided. The longer a debt write-down is postponed, the more the economy will slow down and the more massive and painful the ultimate crisis must be. As long as the debt overhead continues to grow, it will produce pathologies in the economy and in society.

The major pathology is the second dynamic of financialized capitalism: economic polarization between creditors and asset owners at the top, and debtors at the bottom. The post-2008 financial wave has created unprecedented new fortunes for the 10 percent, but this rentier 'growth' model is destabilizing the rest of the economy, not 


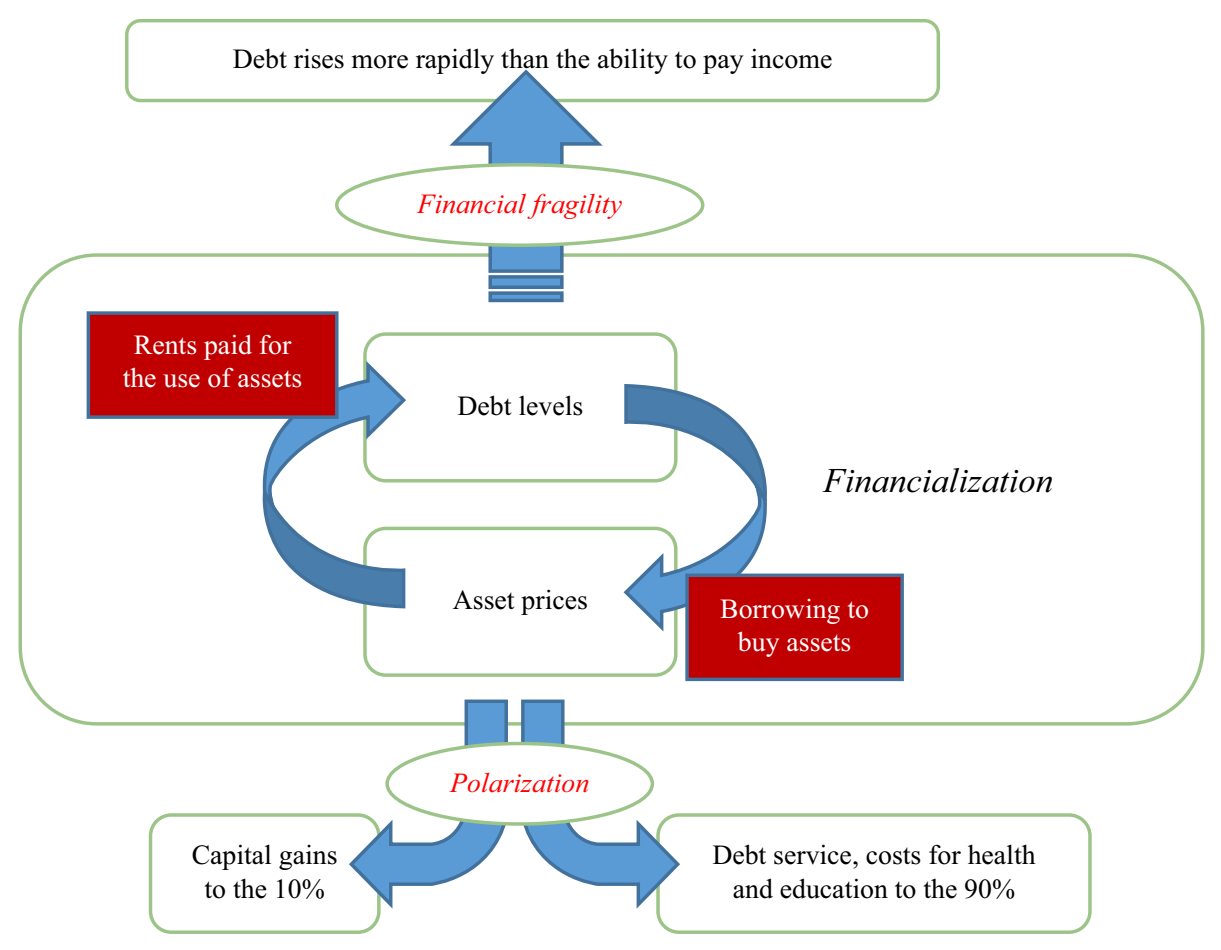

Figure 4 Financialization in America: two consequences

enriching it. Since the 2008 global financial crisis this dynamic has produced capital gains for the richest 10 percent of Americans, but is eating into the disposable spendable incomes of the bottom 90 percent. The Obama 'hope and change' program turned out to benefit Wall Street, not the rest of the economy. By keeping the existing debts in place instead of writing them down, and by deeming the largest Wall Street institutions 'banks' classified as 'too big to fail/jail' (TBTF/J), the US economy was sacrificed to the political system's largest campaign contributors (the donor class).

Before being able to buy the products that they produce, wage-earners must use their after-tax income to pay for housing, debt service on their credit cards and automobile or other debts, compulsory health insurance and medical care via health maintenance organizations (HMOs) ('Obamacare'), education and student debt, and basic utilities taken 'off the top' of their pay checks each month. Most of these debt charges and economic rents are paid to the FIRE sector as debt service and fees, land rent, and monopoly rent. These rentier charges drain income from households and firms in the 'real' production-and-consumption sector to asset owners and creditors in the financial sector. Most land and housing rent ends up being paid to mortgage lenders as interest.

Falling interest rates since the 1980s (reduced to near zero in the last decade) have kept these payments smaller than they normally would have been. Central banks in the United States and Europe have lowered rates specifically to enable the debt overhead to be carried, and hence to avoid default, and indeed to fuel what Treasury Secretary Tim Geithner called 'foaming the runway' for the enormous post-2008 debt take-off. 
The resulting financially engineered boom in asset prices and capital gains has enriched bond-holders and stock-holders (whose asset ownership is highly concentrated), but has left the economy dangerously vulnerable to interest-rate increases, because polarization and financial fragility are inextricably linked.

The American economy therefore has painted itself into a corner. Low interest rates have kept the bond market and banks solvent with a high tide of new corporate, personal, and government debt, but much of the 'real' economy is falling into arrears in the face of the exponential debt wave. Home-ownership rates have fallen as properties have been foreclosed by creditors and sold to new institutional investors such as Blackstone in the booming residential rental market.

Regeneration of the socioeconomic system on a more equitable and sustainable basis requires that the economy break free from this policy. The first step to create support for 'definancialization' must be to create awareness of how the dynamics and character of today's finance capitalism are polarizing the economy and making it more fragile, leaving people more insecure. Their emotional suffering is best understood in terms of the financial and macroeconomic strains that are shaping their psychological condition and making them fearful of losing their middle-class status.

\section{ADDING BALANCE-SHEET 'CAPITAL' GAINS TO NATIONAL INCOME}

To recognize that wealth is accumulated more by capital gains than by saving out of current income, we introduce a new measure: adding capital gains to 'earned' income provides a measure of the economy's total returns. That is what most investors aim for in today's age of financialization.To bring out the financialized nature of capitalism, we view the whole economy as if it were a financial investment.

Balance-sheet relations, headed by credit and debt leveraging as well as tax policies (untaxing income from wealth and shifting the fiscal burden at the federal, state, and local levels onto labor and industry) far outweigh current earnings. That explains why corporations use their revenue for stock buy-backs and dividend pay-outs instead of undertaking new direct investment and hiring. It also explains why real-estate investors are willing to pay most of their rental income to the banks as interest on the loans they take out to buy properties. Their focus is not on net income, but on the prospect of achieving a capital gain on the sale of the property at a higher price. By analysing the economy from their viewpoint, we will better understand the post-industrial logic that drives the system today.

We will show that much of what FIRE-sector lobbyists have persuaded national income statisticians to report as 'earnings' - and corresponding 'output' - is not really earned, but is more in the character of a free-lunch rake-off, or rent. We untangle the most egregious confusions between income and transfer payments (economic rents) that are burdens on output rather than real 'product.' To see how we got here, we first briefly look at the evolution of the GDP framework. This was more fitting for the age of industrial capitalism than for today's financial capitalism.

\section{THE CIRCULAR FLOW OF PRODUCTION COSTS, CONSUMPTION, SAVING, AND TAXES}

Today's basic System of National Accounts was created in the 1930s to focus on the cost of production and how these costs - wages to labor, payments to suppliers, 
business profits, and taxes paid to the government - are distributed and, in turn, spent on consumption, new capital investment, and public programs. The resulting measure of economic activity is the gross domestic product (GDP), defined as the sum of all earned incomes (wages and profit), juxtaposed to the output produced by labor and capital. This accounting format reflects a somewhat propagandistic post-classical view of how industrial capitalism is supposed to work efficiently. All returns are depicted as 'earnings,' even including economic rents not earned by work, innovation, or entrepreneurship in the production process.

The original national accounting principle of circular flow can be traced back to the eighteenth-century French Physiocrats. Their aim was to quantify how large the economic surplus was and how it was distributed, not only among producers (labor and capital) but also to landlords, the major rentiers of the pre-industrial epoch. The political aim was to make land rent France's tax base, freeing labor and industry from the costs of supporting its hereditary landlord nobility whose conquest imposed land rents as a form of tribute. Earlier, John Locke also had said that taxes should fall on the landlord class, because that is where the national economic surplus was concentrated. And classical economics and tax theory focused on who ended up with the economic surplus. 'It is vain in a country whose great fund is land to hope to lay the publick charge on anything else; there at last it will terminate' (Locke 1691 [1777], p. 39).

Adam Smith and subsequent British economists adopted this idea as the basic element of classical value and price theory. isolating land rent and other forms of economic rent as the ideal tax base, and freeing labor and capital from high taxes and prices for food, housing, and other basic needs.

By the 1930s an anti-classical revolution had taken place, asserting that all income was earned, not unearned or predatory. Meanwhile, Joseph Schumpeter's Theory of Economic Development (1934) expanded the view of circular flow between income and production expenditures to include banks. They were assumed to support investment and innovation by creating credit, while individual 'households,' partnerships, and corporations invest in financial markets. In this view, production expands by mobilizing more resources and raising their productivity, enabling consumer spending to rise. Schumpeter recognized that lending also occurred for consumption and speculation, but such 'unproductive lending' was outside of his focus on economic development.

John Maynard Keynes and Michał Kalecki emphasized how new capital investment was dependent on rising wage income to enable consumers to buy what was being produced. Figure 5 depicts this circular flow. In contrast to classical French and British political economy, their models of the industrial economy depicted all returns as incomes, taken as wages or profits. And Keynes and Kalecki, like Schumpeter, emphasized how bank credit augmented the circular flow between consumption and investment. Banks were recognized only as supplying money to producers (and to consumers). On balance, they were not supposed to drain it out of the production and consumption processes. Keynes in particular recognized that this picture was incomplete and that rentiers undermined the economy's circular flow. Yet despite calling for the 'euthanasia of the rentier,' he did not assign them a central place in his theory.

The circular-flow approach formed the basis for Simon Kuznets to develop what has become the dominant GDP model. Government spending on military and other sectors was seen to generate incomes without producing consumer goods. As military spending rose in response to World War II, its role was measured in order to focus on the disparity between income and production. His GDP framework was developed as a policy tool during World War II to keep incomes in line with the production of consumer goods, so as to control inflation. 


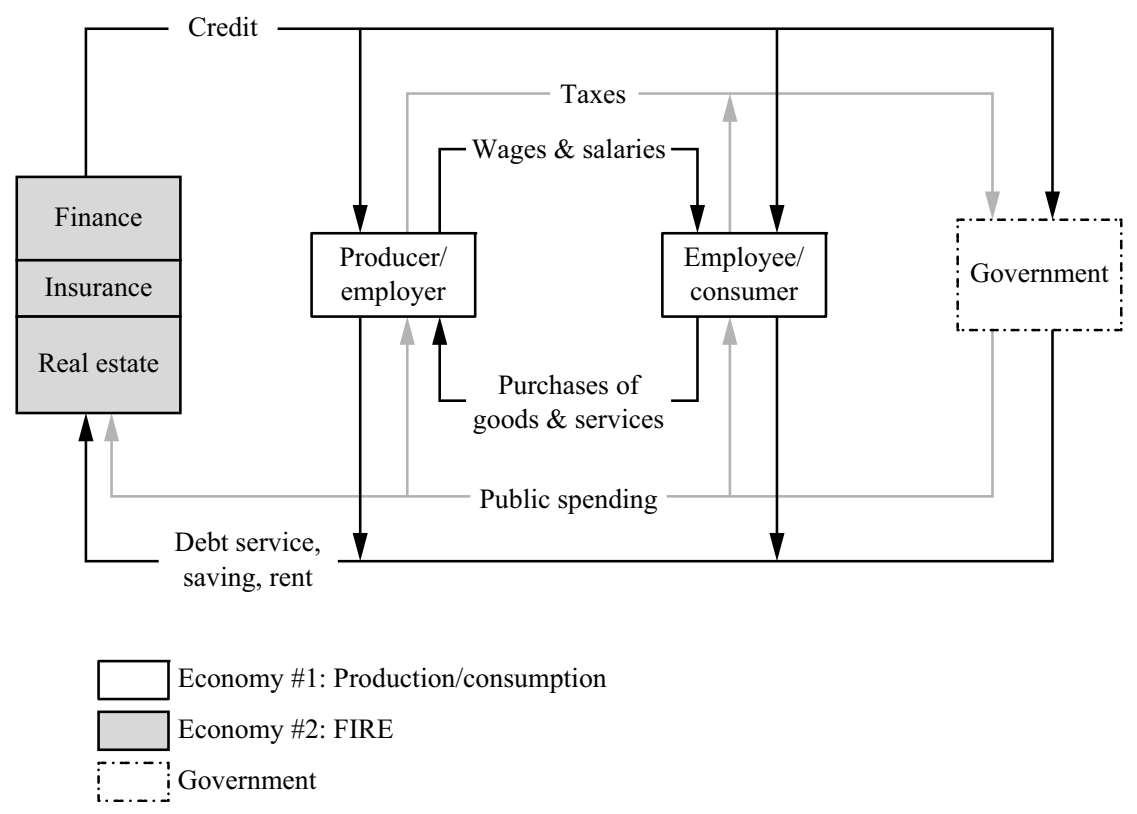

Figure 5 The circular flow of the real economy

\section{ECONOMIC RENTS AND 'CAPITAL GAINS' AS RETURNS BEYOND 'EARNINGS'}

The national accounts bequeathed to us by Kuznets and his followers miss the two most important characteristics of finance capitalism. The first is economic rent. It is not isolated in the NIPA's breakdown of GDP. In fact, economic rent is the blind spot of today's macroeconomics. It is a category of income and increase in wealth that does not involve work or production, but is simply the yield of a property right, legal privilege, or 'patent' to receive income from users of assets that are owned or patented. So rent has no corresponding product. It is a subtrahend, an economic overhead.

Also omitted from the NIPA is a measure of how owners of rent-yielding assets benefit from 'capital gains' as market prices rise for real estate, financial securities (stocks and bonds), property, or patent rights. We put 'capital gains' in quotation marks because rent-yielding assets and their asset-price gains are not capital in the sense of industrial capital - a factory, tools, R\&D, or other actual means of production.

Concern over rising land rent and the resulting land-price gains was central to classical economics. The quintessential rentiers were the land-owners. It was recognized that land rents tend to rise over time in the normal course of things. John Stuart Mill described how a landlord enjoys such rising rents and asset-price gains 'in his sleep':

The ordinary progress of a society which increases in wealth, is at all times tending to augment the incomes of landlords; to give them both a greater amount and a greater proportion of the wealth of the community, independently of any trouble or outlay incurred by themselves. They grow richer, as it were in their sleep, without working, risking, or economizing. What claim have they, on the general principle of social justice, to this accession of riches? In what 
would they have been wronged if society had, from the beginning, reserved the right of taxing the spontaneous increase of rent, to the highest amount required by financial exigencies? (Mill 1818, ch. II, sec. 5)

If Mill had called landlords the One Percent we would immediately recognize the similarity to today's rent extraction. The One Percent, and even the Ten Percent, are the asset-owning class corresponding to the nineteenth century's hereditary landed aristocracy and its ground rents. Today, they are the major designers and gainers from financialization, 'without working, risking, or economizing.' By imposing tollbooth monopoly charges that siphon off income from the production-and-consumption economy, their windfall rentier gains render the economy more polarized and fragile.

As noted above, the political attempt to free economies from such rent-seeking inspired the inception of national income accounting in the mid eighteenth century by the Physiocrats. By measuring the economic surplus, which they saw as generated exclusively on the land, they sought to tax the post-feudal landed nobility instead of labor and industry. François Quesnay, a surgeon to the king of France, applied to the body politick the idea of the circular flow of blood within the human body. At the hands of Adam Smith, David Ricardo, John Stuart Mill, and the reformers in their train, British political economy defined a free market as one freed from the rents siphoned off by landlords, monopolists, banks, and other financial institutions from the rest of the economy, including industry and commerce as well as agriculture.

The late twentieth century saw landlords and bankers fight to reverse this basic political aim of classical economics. Instead of making rentier income the tax base, they sought to untax it. To defend their anti-classical revolution, they redefined a free market as one free for rent-seekers to keep for themselves land rent and monopoly rent. Bankers were given tax favoritism for investors buying rent-yielding properties on credit and paying their rent to creditors as tax-deductible interest. To defend their position, they changed the conceptual framework of national income and product accounting, rejecting the distinction between income earned in the form of wages and profits as compared to economic rent and balance-sheet gains in asset prices.

In reality, wages and profits are only two forms of revenue and the means to obtain wealth. Since the 1980s, economic rents and asset-price gains for rent-yielding assets have become the major ways in which wealth has increased, not industrial investment and earnings. Owners of property receive passive (rentier) income and capital gains on the rising market valuation of their real estate, stocks, and bonds. But the purpose of the NIPA, inspired by the circular-flow framework, is neither to measure asset-price gains nor to draw the classical distinction between earned and unearned income by juxtaposing wages and profits to economic rents from land ownership, monopoly privileges and patents, and finance capital.

From the United States to Europe, middle-class families have seen their net worth rise mainly because of the price of their homes, not through income saved out of their wages and salaries. The tendency is to believe that this asset-price inflation makes them and the economy richer, overlooking how it leaves them and the economy more debt-strapped. The vast majority of asset-price gains since the 2008 crash have accrued to the wealthiest holders of financial assets, to whom the rest of the economy is indebted.

The GDP framework of the circular flow of goods and money in the real economy has become intellectually obsolete. Financialization of real estate, stock, and bond markets has created two new types of return that are not reported as 'earnings': depreciation and capital gains. Figures 10 and 17 show the extent to which corporate cash flow - profit and depreciation - plus new borrowing considerably exceeds new 


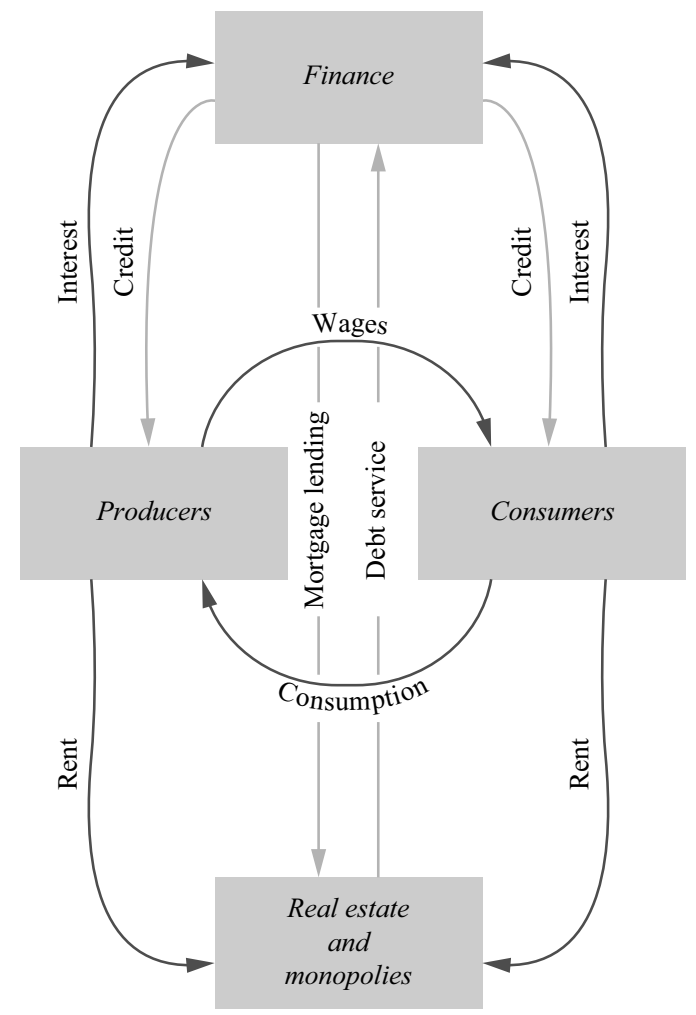

Figure 6 The FIRE sector's intrusion into the economy's circular flow

investment, and thus has become decoupled from real investment as compared to the pre-financialization era before the 1980s (see Figure 6).

\section{SHOULD RENTAL AND FINANCIAL 'SERVICES' BE SUBTRACTED FROM THE NIPA AS NON-PRODUCTS?}

Landlords charge rent for their housing and commercial real estate. Home-owners keep the rising rental value of their homes for themselves. Banks create credit, enabling buyers to purchase such properties. The more they lend, the higher prices rise for these rentyielding assets - financed on credit, with the rental value paid to the banks in exchange for loans to buy homes before rents and housing prices rise yet further.

Some rate of return is necessary to motivate investment, maintain real estate, power grids and factories, and undertake private-sector research to produce new drugs. But pharmaceutical companies price their drugs on which they own patents at whatever the market will bear, without reference to actual costs of production. A century ago, rates of return were publicly regulated, as were interest rates by usury laws. Rates of return for utility companies supplying gas and electricity are still regulated, but not water companies.

It was an article of faith in progressive industrial economies such as the United States and Germany that governments should prevent monopoly pricing for basic 
infrastructure, and indeed to supply basic needs at subsidized prices or freely: healthcare, water, communications, education, and transportation, as well as money and banking services. Progressive income taxation was to fall mainly on landlords, monopolies, banks, and their owners ('coupon clippers').

Every statistical framework is based on some implicit economic theory. Mainstream textbooks, most journal articles, and policy advice euphemize all rental income as 'earnings.' Rentiers and their lobbyists insist that all charges for access to credit, healthcare, education, utilities, insurance, and housing are justifiable and productive costs of doing business for the use of bank-credit-creating privileges and loans, insurance policies, real estate, drug patents, schools, and power and water grids. The effect of the NIPA system of national accounts (rooted in the anti-classical reaction of J.B. Clark in the 1890s) is to leave the public with an impression that unearned rents simply do not exist - as if all non-wage income is profit, and as if everyone 'earns' whatever they can take, regardless of how they obtain it.

To measure the magnitude of rent, and to build a statistical framework relevant to today's financialized economy, we need to draw on the classical tradition by recovering the vocabulary that it developed precisely to create a conceptual framework to measure rent extraction. Only when we statistically identify it can we analyse its role in polarizing today's economies by causing 'rentier austerity' 'or 'rent deflation' for the production-and-consumption economy.

Classical economists deemed legal privileges unproductive to the extent that they enable their owners to charge users of these assets more than what is needed to provide and maintain their services. They drew a clear distinction between costs of production that are economically necessary, and rent charges that are not necessary and therefore are a net burden on the rest of the economy.

Land sites, for instance, are provided by nature, while their use value is a product of public investment in local infrastructure and the level of prosperity. Monopoly privileges for banks and basic infrastructure also are created by lawmakers 'by the stroke of a pen.' Payments to owners of these privileges - privatized and financialized into legal assets - are largely a burden on society's incomes, not an investment in the economy's capacity to generate real output. The income they redistribute as rents to the owners of these rights and privileges are subtracted from incomes in the lower brackets of the distribution.

Unlike paying wages or payments for materials and professional services for production and distribution, rents are zero-sum transfer payments with no real quid pro quo. That is why payments for land rent, monopoly rent, and financial charges should not be counted as part of the economy's 'product.' No value added is realized from paying such rents, so national income does not grow as a result. Such charges and fees are a pure transfer payment redistributing income from renters or users to rentier owners. They are not costs that need to be incurred in order for the productive process to continue. They are best thought of as tolls imposed at the economy's choke points, access charges independent of necessary production costs. These costs are paid by users, and become windfall gain for rentiers, accruing without any productive effort of their own, as Mill and his fellow classical economists emphasized. Such rents do not reimburse the cost of investment to create these assets (land sites or exclusive patent rights), but burden the cost of living and doing business by being superimposed on the economy's production and consumption costs. Their reduction or full removal therefore will not harm production or consumption levels.

Figure 7 is our suggestion for how to measure these rents. There are numerous ways to do so, because the distinction between rent and other forms of income rests on how 


$\begin{array}{ll}\text { \% Housing costs (includes property taxes) } & \text { - Interest } \\ =\text { Insurance } & \text { - Utilities }\end{array}$

\& Health and education
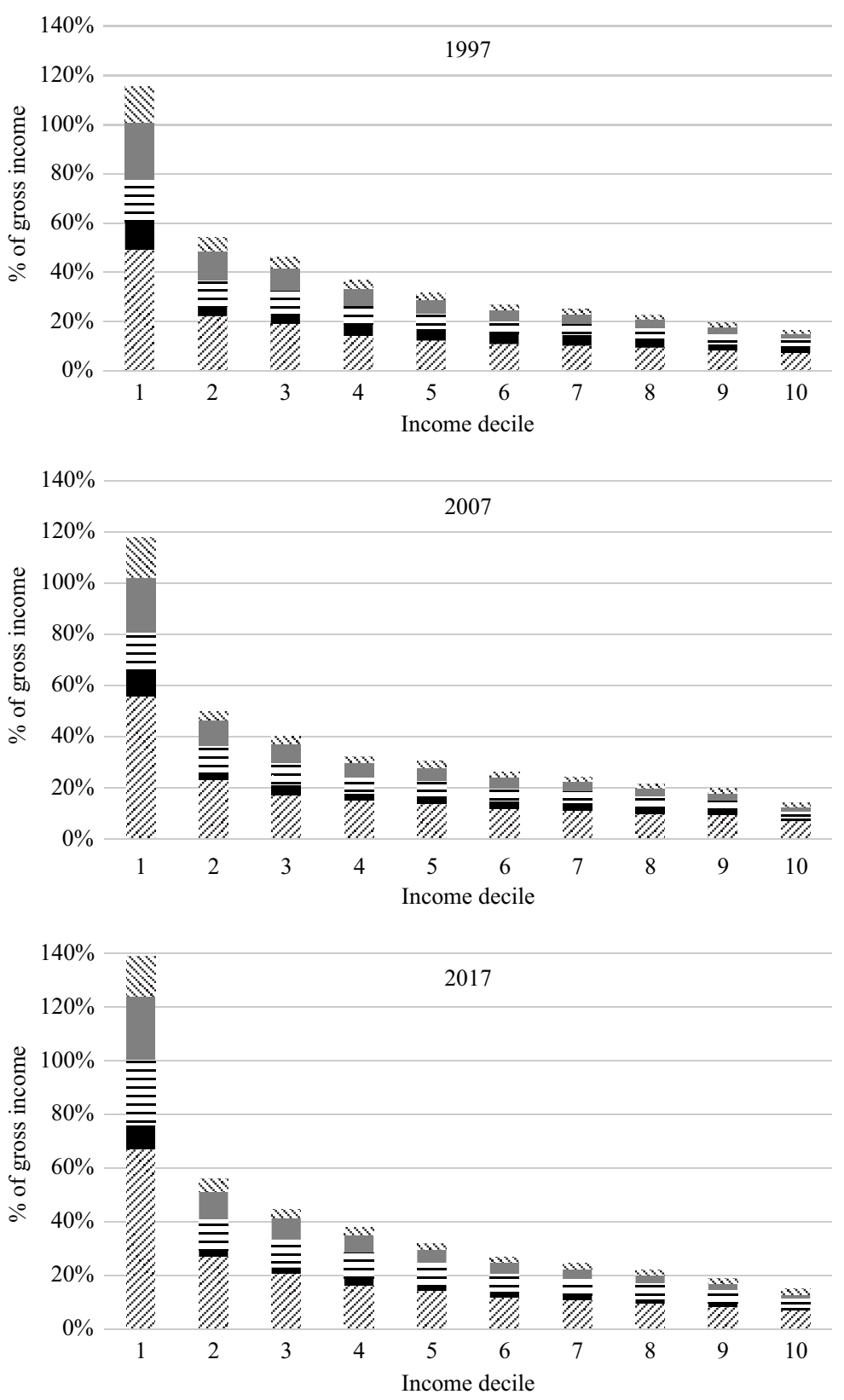

Note: These charts don't include taxes and FICA tax withholding (Social Security and Medicare deductions).

Figure 7 The share of economic rents in pre-tax incomes over income deciles 
the distinction is drawn between returns that are productive, adding value and "product' to the economy, and returns that result simply from ownership rights and hence do not really reflect a 'product' but merely detract from the economy's income. This distinction ultimately is political, as was Kuznets's politically expedient decision to include military expenditure as productive.

To show how regressive and extractive such rentier charges are, Figure 7 deducts them from after-tax incomes for each of the ten income deciles for 1997, 2007, and 2017.

Hardly by surprise, the lower income brackets pay the highest proportion of their income for access to housing, education, and other necessities - let alone to maintain consumption. For the lowest income decile, these deductions are more than 100 percent of income. The poorest 10 percent receive public subsidy in addition to their reported income. Still, they are obliged to pay a higher percentage of their income as interest, especially because they are more driven to resort to usurious payday loan sharks as well as having to pay higher penalty interest rates on their credit cards.

A second noteworthy trend is that, for the bottom 30 percent, total subtractions rose as a share of income after the 2008 global financial crisis. And in fact, most likely these Federal Reserve figures substantially understate the housing burden for most people. Housing costs are about 15 percent on average for the bottom 50 percent. But private studies and media reports show that housing costs have risen much more than incomes, absorbing a larger and larger proportion each decade. The fact that the US government (FHA, Fannie Mae, etc.) guarantee personal home mortgages absorbing up to 43 percent of an applicant's income gives an idea of the proportion of income that many home-buyers have to pay. The Bureau of Labor Statistics (BLS) Consumer Expenditure Survey Public-Use Microdata 1996-2014 reports that households in the lower third spent 40 percent of their income on housing - and renters nearly half (as of 2014). ${ }^{1}$ This suggests that something is seriously wrong with the Federal Reserve's statistics. Given this anecdotal empirical evidence, these charts based on official statistics are only a very conservative estimate of the extent of inequality in the distribution of the burden of subtractions from pre-tax incomes that is due to the FIRE sector and kindred monopolies. The official statistical methodology, by implying that the FIRE-sector deductions have barely risen as a proportion of GDP for every income decile from 1998 to 2007 to 2016, has become far removed from financial reality. This is why we need this research project to start piecing together the data that depict the true state of polarization in America.

For the moment, the official statistics are all we have, and the trends they show are already bad enough. Figure 8 shows the change in rentier deductions as a percentage of income over two decades. No change occurred for the top decile, but for the middle decile it rose from the mid 2000s to 3 percent in 2017 and at a rate ten times larger for the bottom decile, to $20-30$ percent.

Rising rents typically are associated with rising debt. Installment consumer loans (led by automobile loans), credit cards, student debt, and home mortgages have increased massively relative to income (Figure 7). As has become the post-1980 norm (accelerating since 2008), this trend is regressive. For the lower 50 percent of the income distribution, household debts relative to income rose by half in the decade

1. Based on the Bureau of Labor Statistics (BLS) Consumer Expenditure Survey, Public-Use Microdata 1996-2014 reports that households in the lower third spent 40 percent of their income on housing. See also Carter (2019). 


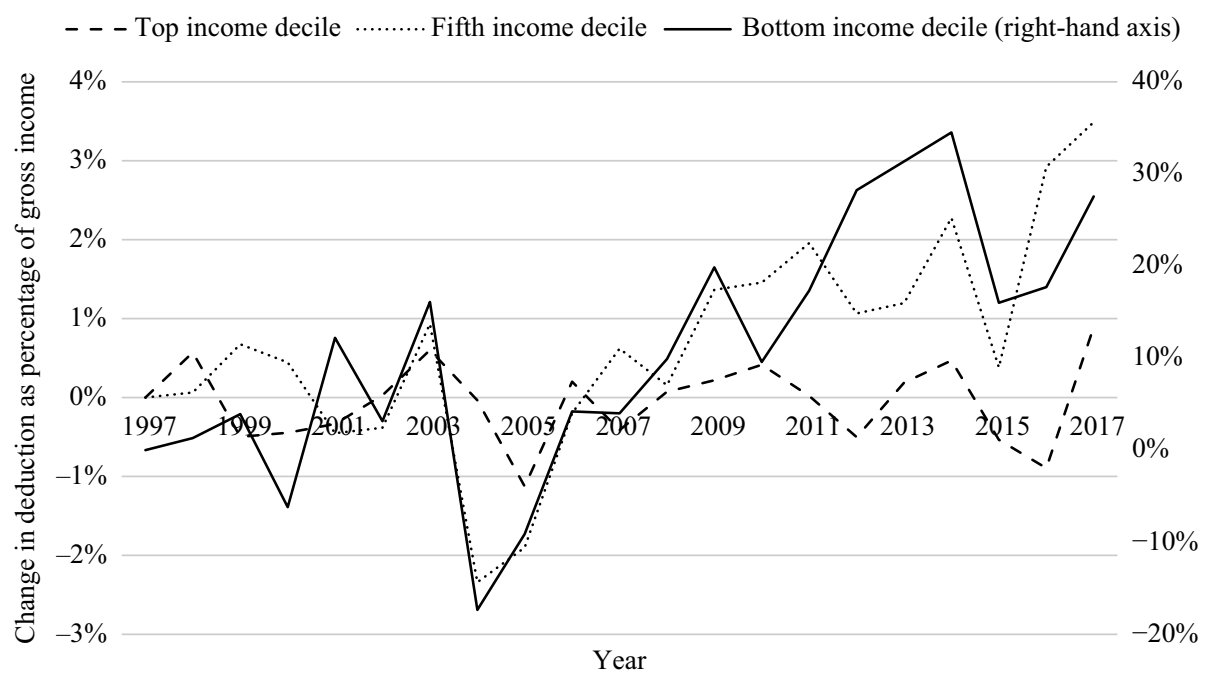

Figure 8 Change in rentier deductions, as a percentage of income

leading up to 2007. Even for the low incomes the rise in debt in those years was enormous - about a third. Only the top 10 percent saw virtually stable debt-income ratios. Debts fell in the decade after the global financial crisis (mainly because mortgage lending stopped as home-ownership declined as a result of arears and foreclosures). But income growth was also negative, so that leverage has remained roughly stable (see Figure 9).

These distribution charts show that after the 2008 global financial crisis, rental privileges remained the prime category of asset ownership. It is therefore necessary to measure the extent to which such rent-seeking is superimposed on today's post-industrial economy, eating into the circular flow of production and consumption spending.

\section{DOES FINANCIALIZATION CONTRIBUTE TO ECONOMIC GROWTH, OR IS IT A RENTIER OVERHEAD?}

Nowhere is the NIPA's divergence from reality more visible than in the treatment of depreciation, specifically for the real-estate sector which the Internal Revenue Service (IRS) has estimated accounts for some 80 percent of reported depreciation. ${ }^{2}$ There are two sources of statistics on real-estate depreciation, and each source has quite different aims. That of the IRS is to measure the actual flow of income within the economy, and to apply the tax law to this income. Over the years, lobbyists for the real-estate sector and its financial backers have created a widening divergence between the picture produced by tax filings and that which the NIPA report in measuring 'real' product and its income flows. The NIPA's reported picture of reality does not reflect why Donald

2. The IRS's Statistics on Income is published every decade or so to provide benchmark data. That is the sole source of information on what real-estate investors actually claim on their income-tax returns. 
450 Review of Keynesian Economics, Vol. 9 No. 4

2 Instalments $\square$ Credit cards $\square$ Other $\$$ Mortgages

1998
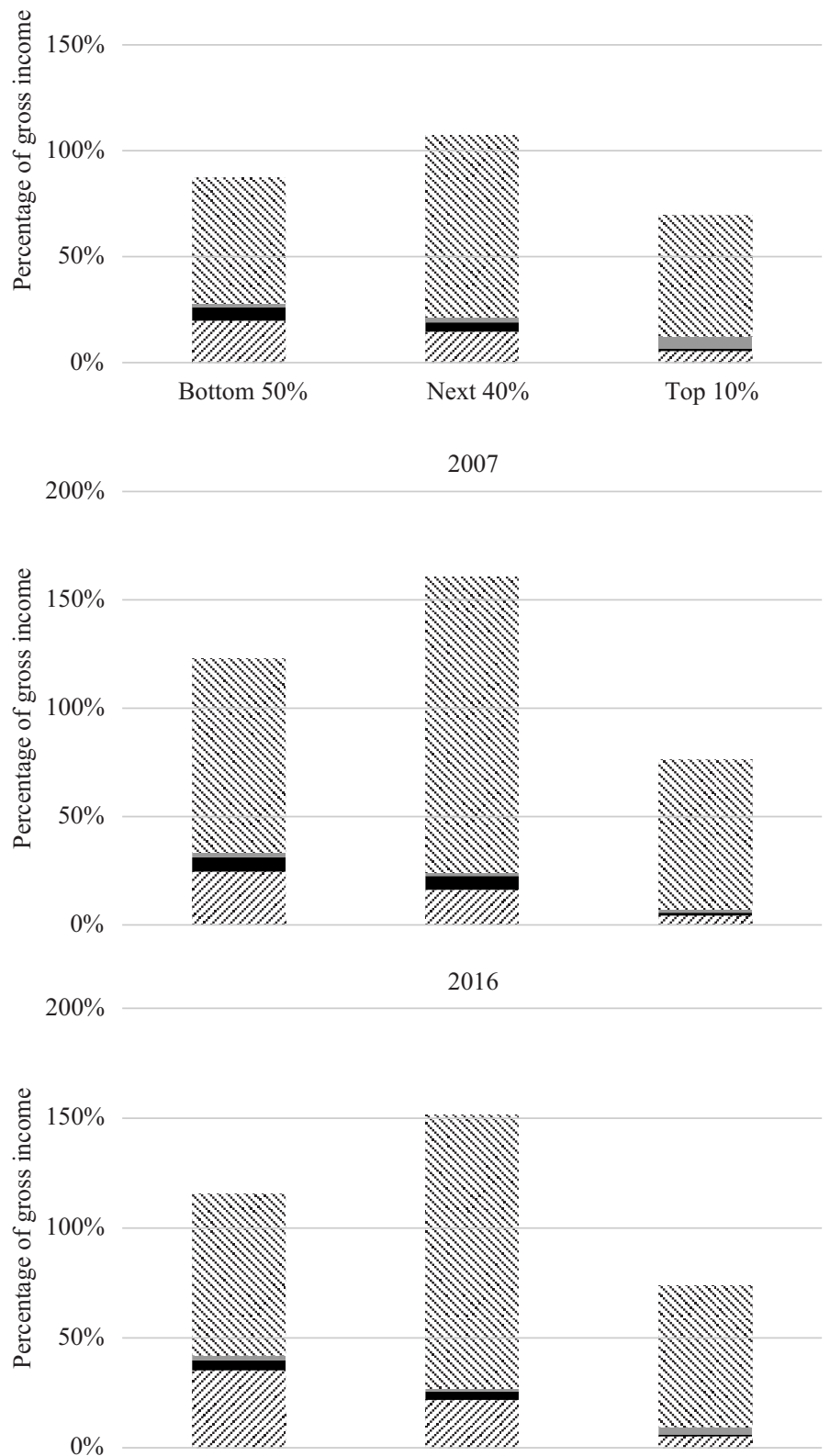

Figure 9 Holdings of debt as percentage of income: the debt burden (percentage of income) has risen for the 90 percent, but not for the 10 percent 
Trump said that he loved depreciation, because it enabled his accountants to show a book loss instead of taxable income. By trying to depict physical reality rather than the actual financial income flows, the NIPA statistics overlook the financial reality of how investors use various pretenses that the tax code permits absentee owners of real estate (but not home-owners) to use.

Depreciation is revenue that is supposed to reflect the rate at which a building, factory, or capital good wears out or becomes obsolete. The logic in making this revenue tax-exempt is to enable investors to recoup their original investment, as distinct from profits or rents on this investment. But do buildings really wear out? And if they do wear out, whether at the assumed rate of anywhere from seven years (under the Reagan Administration's double declining balance method of calculating depreciation) to 30 years (the NIPA's 'real' figure), why are so many buildings still standing that were built before 1990?

The answer, of course, is the rule of thumb that landlords typically spend about 10 percent of their rent roll on maintenance and repairs precisely to prevent buildings from wearing out and depreciating. But the NIPA - supported by Federal Reserve balance-sheet statistics in its quarterly Flow of Funds reports (table Z) - show a deep confusion at work. Is it realistic for a building that has been depreciated and its value recaptured once, to be depreciated over and over again, each time at rising prices? That is what the US tax code permits. Each time a real-estate property is sold, assessors attribute a portion of the price gain to the building.

A more realistic appraisal would be to assign this valuation to the land, not to the landlord's capital investment in the building. The effect of this mis-attribution is to enable real-estate investors to take most of their net rental income in the form of tax-exempt 'depreciation.' Over-depreciation would be a more appropriate term.

NIPA economists realize that the statistic they report for the real-estate sector (table 6.13D for partnerships and proprietorships, and table 6.22D for corporate owners) is not the actual revenue accruing to real-estate investors, but a non-financial imputation for how much the building 'loses value' as a result of wear and tear or other depreciation (even as the property's price soars!). ${ }^{3}$ This practice prevents a realistic estimate of how much money real-estate investors actually are making tax-exempt, as Donald Trump has explained: 'I appreciate depreciation. For me the relevant issue isn't what I report on the bottom line, it's what I get to keep' (quoted in Reilly 2016). The fact that there seem to be no published statistics to measure this reflects the power of real estate and financial lobbyists to prevent popular awareness of just how large and egregious the false pretenses of over-depreciation really are.

Despite the steady rise in land prices (Figure 10) and hence building values, tax depreciation (and even NIPA calculations) imply that they are losing value. Realestate investors understandably do not want to publicize the extent to which their fortunes reflect these special breaks, based on fictitious assumptions favoring rent recipients at the expense of the tax collector. Depreciation has become a major category of real-life EBITDA - earnings before interest, taxes, depreciation, and amortization.

The effect of this tax 'loophole' (that is, the pretense subsidized by political lobbyists) is to subsidize cash flow to fund new financial investment, helping asset prices rise. That has become the guiding logic of financial capitalism: to maximize financial flows into the real estate and financial markets, thereby creating a debt market.

3. The details are spelled out in https://apps.bea.gov/iTable/index_FA.cfm, especially table 3.4ESI, and explained in https://apps.bea.gov/national/pdf/chapter13.pdf. 


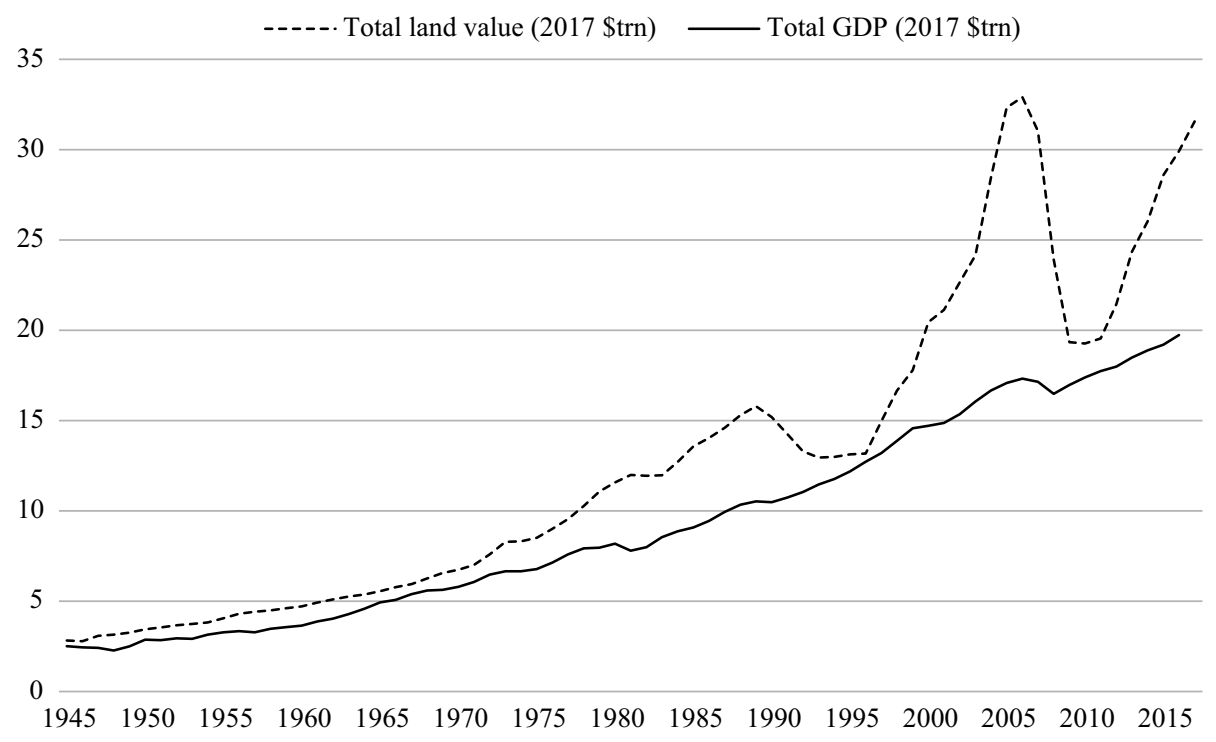

Figure 10 Land value compared to GDP trends, 1945-2015

The 'productivity' of debt is measured by its ability to increase asset prices faster than the rise in debt, thereby increasing total returns. The problem for the economy at large is that this financial gain-seeking drains revenue away from the circular flow of real investment and consumption instead of reinforcing it. So what is financially remunerative ('productive') tends to impair tangible capital formation and productivity in the 'real' economy.

\section{HOME-OWNERS' IMPUTED RENTAL VALUE}

In contrast to under-reporting the depreciation revenue that absentee real-estate investors receive tax-free, the NIPA add an estimate for 'home-owners' implicit rent.' This is a 'real-estate service' that does not involve any revenue in the economy's actual flow of spending and receipts. It is what home-owners estimate they would have to pay themselves if they had to rent their home instead of owning it. This estimate accounts for some 8 percent of reported GDP (Figure 11).

This imputed rental value does not involve any actual payment or receipt of income. Is it even really a 'product'? Rents have indeed increased sharply since the post-2007 wave of home foreclosures causing a nearly 10 percent decline in US home-ownership rates (from 69 percent to 64 percent; Figure 12) and declines in mortgage lending and new residential construction (except for the very high end).

According to the NIPA, the combination of housing shortage, rising home prices, and corresponding increases in rents (charged to the one-third of the population who do not live in their own homes) means that home-owners who would receive exactly the same living environment as before should nonetheless be credited with receiving an increased 'product.'

A realistic format to describe the economy would reflect how wealth is acquired increasingly by capital gains, not by saving out of profits and wages. But it is mixing 


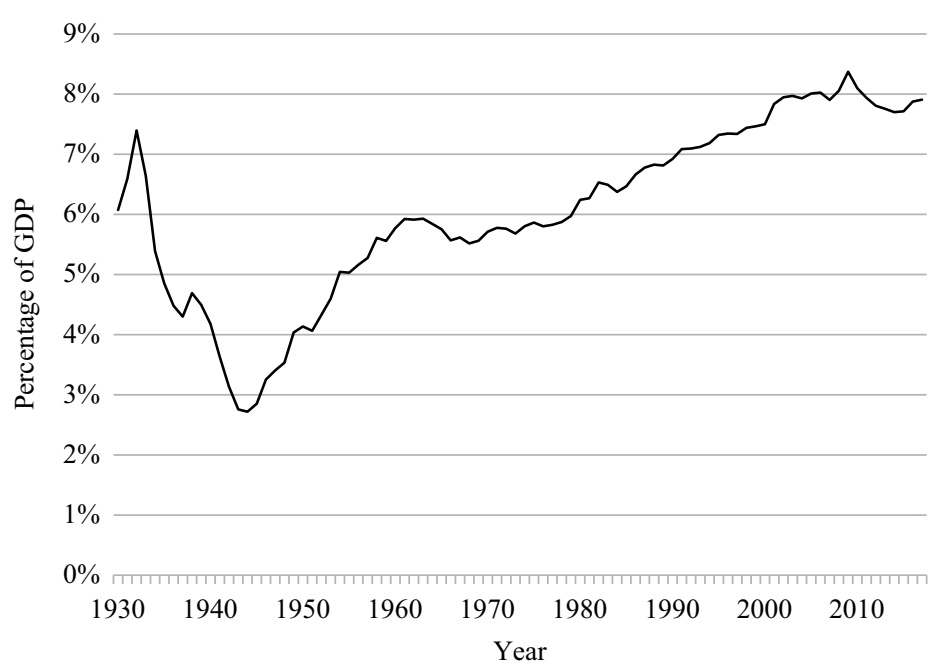

Source: NIPA table 2.4.5, line 52.

Figure 11 Imputed rental value of owner-occupied housing as a percentage of GDP

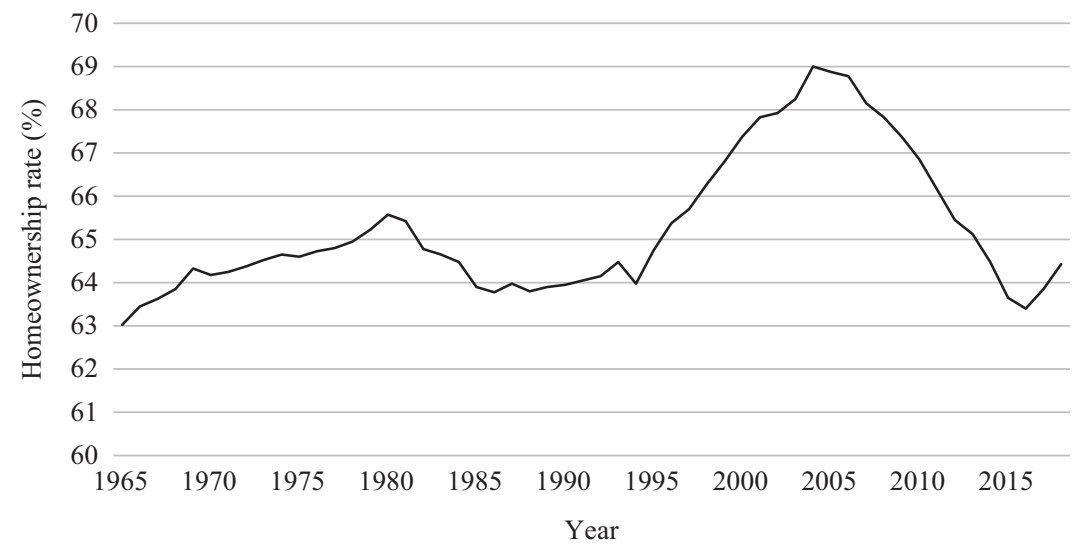

Figure 12 Home-ownership rate (percent)

'apples and oranges,' balance-sheet capital gains and the core economy of production and consumption treating the imputed housing costs in Figure 11 as a 'product' and hence contributing some 8 percent of GDP - and rising as America's rent squeeze intensifies. ${ }^{4}$

Lobbyists for the FIRE sector have a vested interest in wrapping a cloak of invisibility around rent extraction and wealth created by financial instead of industrial

4. The NIPA does publish a statistic for 'real GDP' by deflating each year's reported numbers with a statistic for price inflation (the GDP deflator, based largely on a selected consumer price index to reflect the cost of living). 


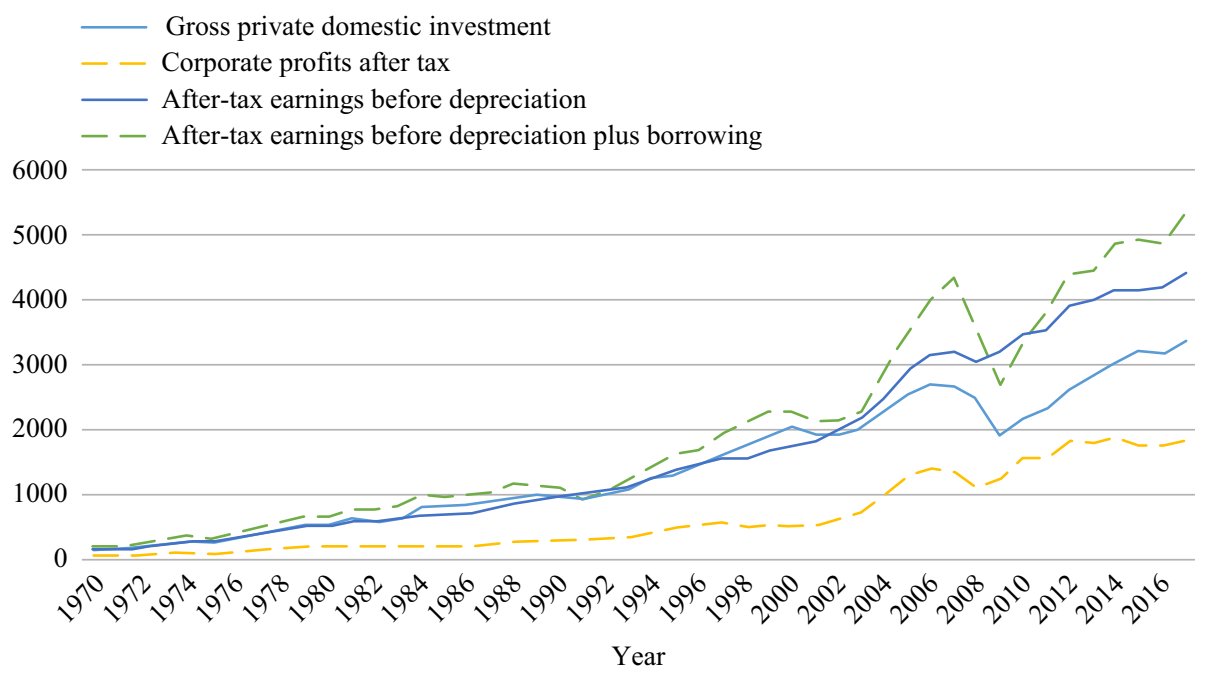

Figure 13 The sources of corporate money (\$ billions) comparing profits, depreciation, and borrowing relative to investment

engineering. They have played a major role in shaping the NIPA to conceal the magnitude of their rents by denying the classical contrast between earned and unearned income. To avoid being taxed, the FIRE sector, monopolists, and other rentiers seek to distract attention from how they got wealthy by shifting the fiscal burden onto productive industry without playing a productive economic role themselves.

The working assumption (that is, the financial cover story) is that cash flow classified as depreciation will be reinvested, replacing depleted or obsolete capital stock. But after-tax profit far exceeds the private sector's tangible new capital formation. As noted above, the difference is explained by the fact that most cash flow is paid out as dividends or used for stock buy-back programs.

After-tax earnings including depreciation almost coincided with investment until the mid 1990s, and hence was sufficient for this investment to take place (see Figure 13). Borrowing therefore was not necessary for investment purposes. And except for a few exceptional recession years $(1991,2002$, and 2009) when corporate cash flow fell so low as to be fully absorbed by investment, after-tax earnings and depreciation plus new borrowing were well in excess of real investment. Firms used this excess to pay their bond- and stock-holders, and to buy up their own stock to support its price - creating financial valuation without increasing production.

After 2002 a new financial boom started. Profits exceeded new investment by a wide margin, yet borrowing continued to rise unabated. Since 2000, its magnitude closely paralleled that of stock buy-back programs (Figure 14). So, in view of the fact that stock buy-backs have accounted for the largest part of debt growth since the late 1990s, one could just as well say that firms use borrowing to buy back their own stocks as to say that they use their income for this purpose.

The upshot is that net US saving is only a quarter of gross saving. It used to be half. There is still plenty of gross saving, but it is not being invested in tangible capital formation. It is used to buy assets - creating capital gains in the process. 


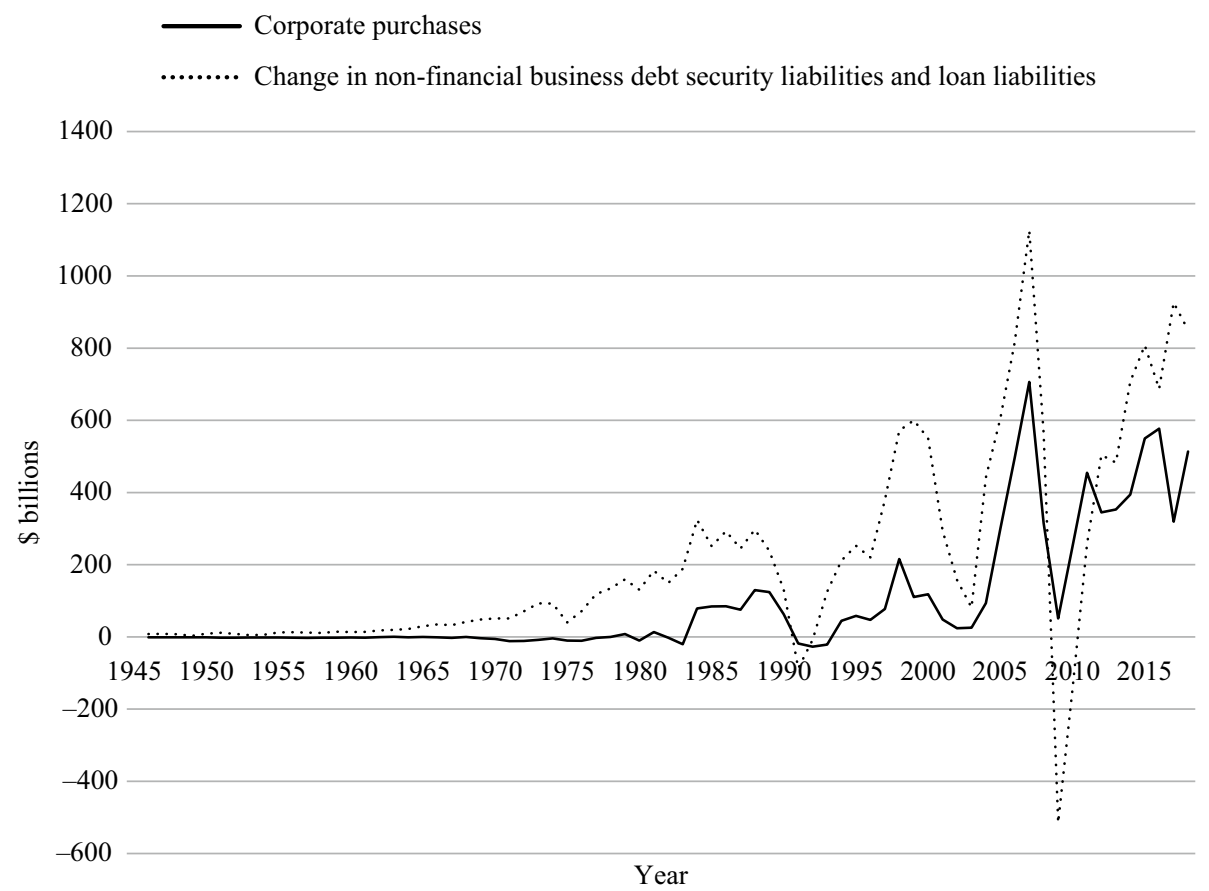

Figure 14 Stock buy-backs track debt growth since the early 1980s

\section{HOW TO MEASURE RENTS?}

Economic polarization between the FIRE sector and its allied monopolies vis-à-vis the rest of the economy (labor, industry, and the government) is the defining characteristic of the post-2008 period. Distinguishing the productive activities of production and consumption from economic rents shows the degree to which asset prices reflect the capitalization not only of productive capital investment but even more of rentier opportunities to extract land rent, monopoly rent, and financial charges.

Rental payments for legal property rights (literally a privilege, from Latin 'private law' [leges]) are external to the necessary costs of production. Likewise, in today's financialized economy, credit and its interest charges (and inflation of asset prices) are external both to the rentier economy and to the industrial economy. Their cost of production is minimal (bank credit is created on computers), but their returns are large. The main effect of the financial sector is to inflate asset prices on credit, producing capital gains while increasing the economy's debt overhead. The main way to obtain capital gains today is to borrow credit to buy rent-yielding assets, and to persuade governments to untax this revenue.

There are various dynamics that national-income and product-accounting formats may wish to measure to track an economy's course. From the Physiocrats through Adam Smith, John Stuart Mill, Alfred Marshall, and other classical economists, the aim of national income accounting was to isolate income that was deemed unnecessary for production, but simply added to the economy's cost of living and doing business. Classical economics was basically the progressive reformist expression of industrial 
capitalism as it sought to free itself from the legacy of feudalism: land rent, monopoly rent, and predatory banking. These forms of overhead were seen to leave unreformed rentier economies uncompetitive. The classical solution was to tax away the rent of location for land sites, and to take natural monopolies into the public domain so as to prevent monopoly rent.

As noted above, by the time the NIPA was formulated in the 1930s, an anti-classical reaction had been mounted. The rentier classes claimed that economic rent did not exist, and that their revenue as landlords, monopolists, and bankers was not a form of overhead but was necessary for industrial economies to function. The NIPA measures more than what the US economy produces, and how income from this productive activity was distributed. It includes rentier income and leaves out of account the costs and returns associated with the balance sheet of property, credit, and debt.

The aim of the NIPA's GDP format thus is different from classical political economy. All ways of making an income were deemed to be productive. No legal income-making activity was deemed unproductive or a form of overhead, even rentier activities that simply transfer income from asset-users (renters, consumers of monopoly products, and debtors) to asset-owners (landlords, monopolies, and the financial sector). Egregious examples include the treatment of financial services (late fees, penalties, and 'accrued interest') as 'product.'

The intellectual legacy of the GDP/NIPA accounting format has been distorted by including many lines that are the result of political lobbying. Our discussion of overdepreciation credits to the real-estate sector shows the degree to which tax favoritism rests on economic pretense that the landlord's rent is offset by a hypothetical physical deterioration of the building and hence a financial loss. The tax code permits absentee real-estate owners (but not home-owners) to pretend that their buildings (and 'capital improvements') are losing value, despite the fact that they rise in price over time, and also include much capitalized land valuation $a s$ if it were part of the building. Also, 'imputed rent for home-owners' pretends that, as home prices are inflated on credit and rents rise (along with mortgage debt), this adds to GDP.

Figure 15 shows two of the most egregious inclusions: imputed homeowners' rent, and 'financial services,' for example in the form of penalties for late payment, speculation, etc.

What has occurred is an inversion of values about the proper aim of economies. Today, it is to get rich by means of a financialized rentier economy. From the point of view of rentiers and other investors, the production-and-consumption economy is the overhead. The costs of labor and capital are to be minimized by squeezing out more economic rent. By contrast, our approach treats the production-and-consumption sector as primary, and the FIRE sector and other rent-extracting sectors as overhead.

The statistical apparatus developed for industrial capitalism does not explain how the financialized aim is to increase market prices for wealth (real and financial assets) in ways external to the 'real' industrial economy. To describe 'total returns' beyond the categories of profits and wages, it is necessary to take capital gains into account, because they are the main aim of today's financialized investment, and even of official policy. Taken together, bank credit, tax-free depreciation revenue, stock buy-back programs, and Federal Reserve quantitative easing have channeled liquidity into the financial and real-estate markets to push up asset prices, creating capital gains for asset-owners. Most of the beneficiaries are concentrated at the top of the 


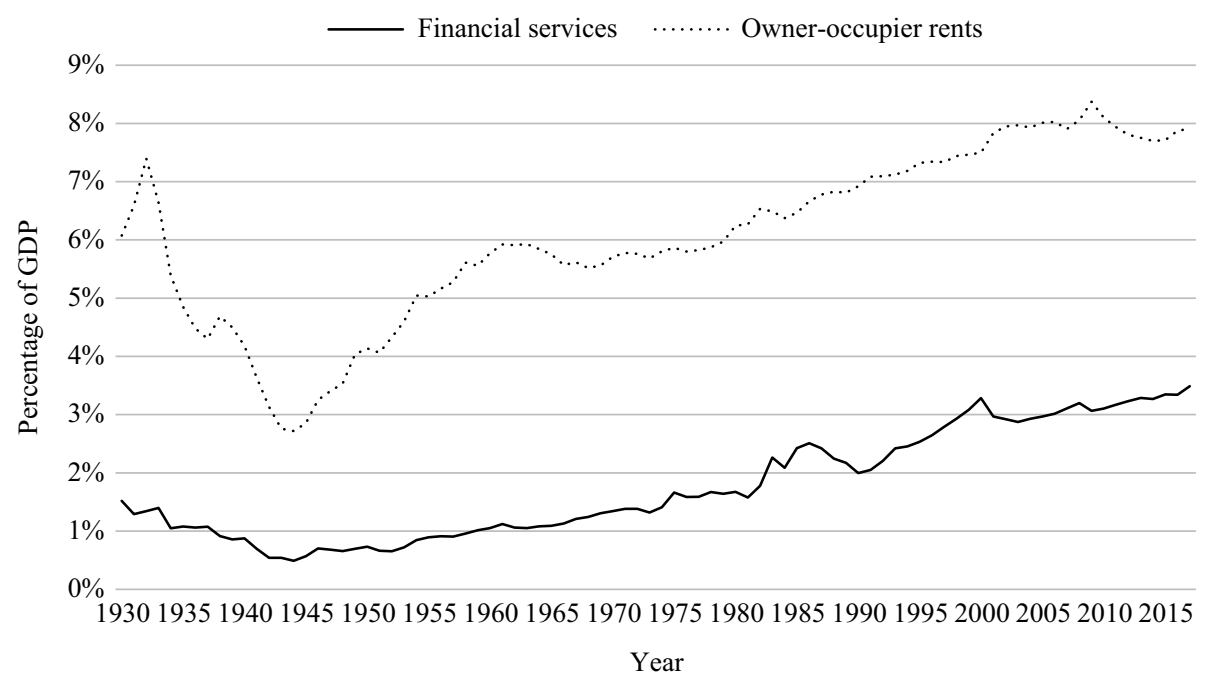

Figure 15 Imputed financial services and imputed owner-occupier rents as a percentage of $G D P$

economic pyramid, especially the top 10 percent, who recycle their gains as loans to the rest of the economy or spend on buying up more assets, with a preference for those yielding economic rents.

Capital gains are today's leading category of returns in financialized economies. To trace this distinguishing phenomenon of our era, a measure of total returns is necessary: earnings plus depreciation and interest (cash flow after taxes) plus capital gains. All these returns have been financialized, creating a new circular flow of cash flow plus debt (credit), asset price gains, and new financial investments and asset purchases, above all to rent-yielding sectors. This financial circuit cuts in to the 'real' production-and-consumption economy's circular flow. The rising debt overhead, coupled with tax favoritism for finance, makes real investment and consumption less liquid.

The term 'EBITDA' is often confusing to financial outsiders. It refers to total cash flow ('earnings,' including unearned economic rent) before subtracting interest, taxes, depreciation, and amortization write-offs. This jargon reflects the degree to which financial analysts recognize that cash flow is much larger than what the NIPA report. GDP includes accounting profit but not the depreciation that real-estate owners claim on their tax returns and hence 'get to keep,' in Donald Trump's words. Depreciation is a large part of total returns in the real-estate sector, where most of it is claimed in US tax filings. It is rental revenue deemed tax-exempt, a giveaway to $\mathrm{Mr}$ Trump and other absentee owners.

\section{INCORPORATING TOTAL RETURNS INTO ECONOMIC STATISTICS TRACING WEALTH DISPARITIES}

We are now in a position to integrate the preceding analysis into a macroeconomic measure to explain why financialized economies polarize and end up imposing 


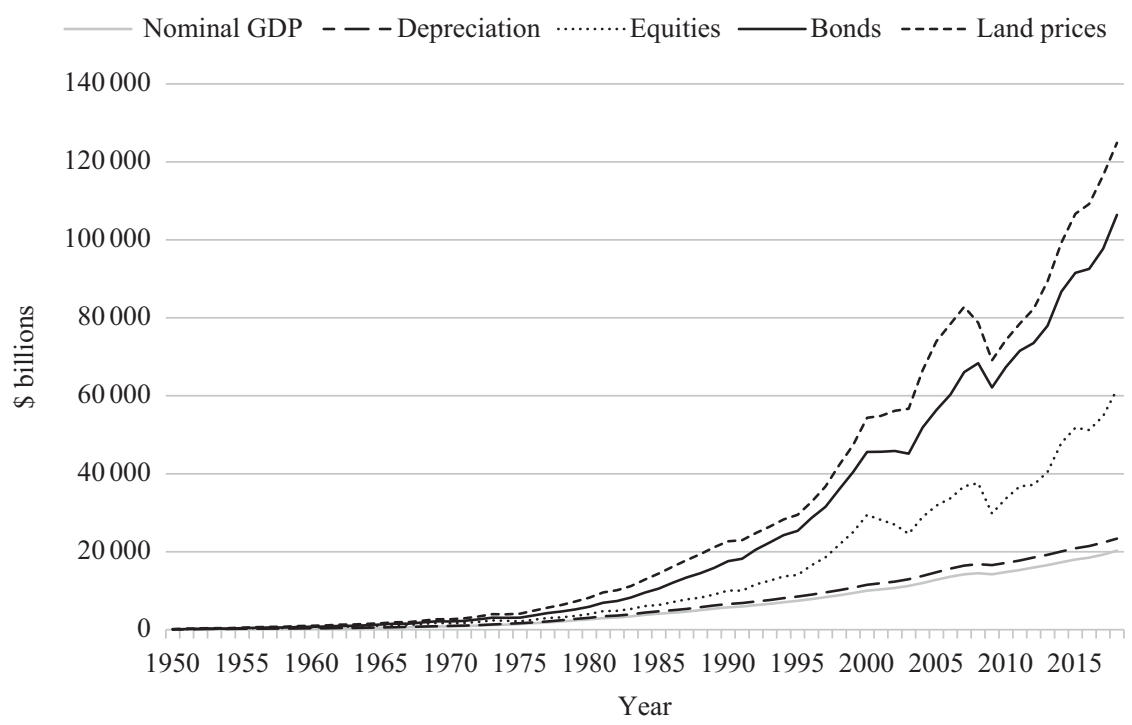

Figure 16 Total returns in the US, 1950-2017: GDP and year-on-year changes in equities, bonds, and land values (nominal, \$ billions)

financial and fiscal austerity. We find the standard practice of securities analysts to be appropriate: In addition to cash flow (EBITDA) in the GDP 'real economy' measure, we add in overdepreciation in real estate, and also capital gains so as to trace 'total returns.' This is the best available measure to trace the sum of all income (GDP net of economic rent deemed to be merely a transfer payment) plus depreciation, plus price gains of the three largest asset classes: land-value gains and capital gains on stocks and bonds. ${ }^{5}$

Calculating total returns allows us to do what is not possible in the GDP-based production-focused system of national accounts. Bringing together income and changes in wealth enables us to explain today's widening disparities in the distribution of wealth and income by tracing the economy's actual gains (or losses) (Figure 16). To paraphrase hotelier Leona Helmsley, only the poor people get GDP and pay taxes; the rich 10 percent, and especially the One Percent, get capital gains and tax breaks.

This figure shows how wealth is made much more by making capital gains on real estate, stocks, and bonds than by earning wages and profits. By 1982 the annual increase in market capitalization of the bond market overtook the annual GDP in magnitude. It has risen exponentially as the Federal Reserve has driven down interest rates, increasing the capitalized value of a given income. The widening polarization of income and wealth thus has been a deliberate public policy. The Treasury has untaxed rentier and corporate income, showing special tax favoritism to real-estate finance while the central bank has supported easy financing (with bail-outs for banks making bad or outright fraudulent loans).

Supporting these rents and capital gains, the financial sector has grown increasingly dysfunctional. The increase in capital gains has been largely debt-financed. Each debt

5. We recognize that interest, dividends, and new debt (mainly used for stock buy-backs) may fall short of capital gains. 


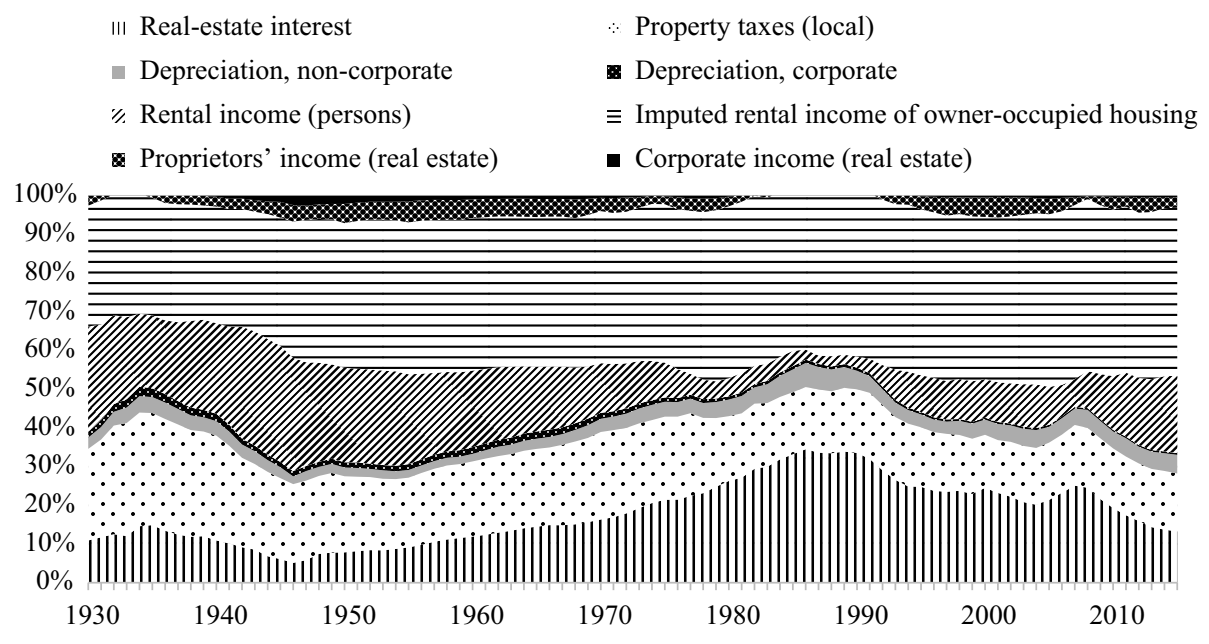

Figure 17 Composition of real-estate EBITDA, 1930-2015

is a credit on the other side of the balance sheet, because behind each borrower is a lender. The vast majority of new financial investment and bank loans are issued to acquire (that is, transfer ownership of) existing real-estate assets, corporations, and their stock. By driving up prices for these assets, this financial system causes homebuyers to take on deeper debt levels. The effect is to divert more income to paying interest and much less to property taxes. Absentee landlords have paid scarcely any federal taxes, thanks to the tax-deductibility of what they report for interest and depreciation (Figure 17).

\section{CONCLUSION: TOWARDS A MORE REALISTIC PROFILE OF THE FINANCIALIZED RENTIER ECONOMY}

The figures shown in this paper illustrate the economy's actual dynamic, to suggest entry points for policy interventions. The logic and policy values are basically those of nineteenth-century classical political economy, above all distinguishing the rentier economy from the production-and-consumption economy so as to make rent distinct from profits.

We draw on existing statistics to show that:

1. most wealth is achieved by asset-price gains for real estate, stocks, and bonds, not by saving up earnings out of wages and profits;

2. much of what are called 'earnings' are actually economic rent - revenue that landlords, monopolists, and banks charge, at prices that are unrelated to the cost of the production process;

3. banks and bond-holders prefer rent-yielding assets precisely because they have no inherent cost of production. Land prices reflect the rent of location and bank credit is created simply on a computer keyboard (or as it used to be phrased, 'by the stroke of a pen');

4. prices for rentier assets yielding these revenues are inflated largely by bank credit, indebting the new buyers. As credit terms are 'loosened' by longer 
maturities, lower downpayments, and higher limits on debt-income ratios, bank credit tends to inflate asset prices;

5. banks and bond-holders recognize that whatever the tax-collector relinquishes is 'free' to be to be paid as interest, an incidental political effect of rising debtincome ratios transferring property management to the financial sector in a client relationship, while endowing the FIRE sector with the economic power to lobby for tax favoritism for rentier activities; and

6. by far the main cause of today's economic polarization is debt-financed capital gains. The financial overhead that fuels this process is shrinking the economy, not helping it grow.

\section{REFERENCES}

American Psychological Association (2015), 'American Psychological Association survey shows money stress weighing on Americans' health nationwide,' 4 February, available at: http://www.apa.org/news/press/releases/2015/02/money-stress.aspx.

Carter, Shawn M. (2019), 'The top 10 US cities where rents have increased the most,' CNBC, 4 January, available at: https://www.cnbc.com/2019/01/04/the-top-10-us-cities-where-rentshave-increased-the-most.html.

Federal Reserve (2018), Report on the Economic Well-Being of U.S. Households in 2018, available at: https://www.federalreserve.gov/publications/files/2018-report-economic-well-beingus-households-201905.pdf.

Gibson, William E. (2019), 'Nearly half of Americans 55+ have no retirement savings or pension benefits,' AARP, 28 March, available at: https://www.aarp.org/retirement/retirementsavings/info-2019/no-retirement-money-saved.html.

Locke, John (1691 [1777]), 'Some considerations of the consequences of the lowering of interest, and raising the value of money,' in The Works of John Locke in Nine Volumes, vol. 2, London: Rivington.

Mill, John Stuart (1818), Principles of Political Economy, with Some of Their Applications to Social Philosophy, Book V, London: John W. Parker.

Reilly, Peter J. (2016), 'Donald Trump's deep love of tax depreciation - an affair to remember,' Forbes, 10 October.

Schumpeter, Joseph A. (1934), The Theory of Economic Development: An Inquiry into Profits, Capital, Credit, Interest, and the Business Cycle, Cambridge, MA: Harvard University Press.

Trump, Donald J. with Tony Schwartz (1987), Trump: The Art of the Deal, New York: Random House. 